Boban Arsenijević*

University of Graz, Austria
UDK 811.163'367.622:81'373.611

DOI: $10.4312 /$ linguistica.60.1.7-29

\title{
DEVERBAL NOUNS IN -IE AND THEIR VARIATION ACROSS THE SOUTH SLAVIC AREA
}

\section{INTRODUCTION}

The suffix -ie occurs throughout the Slavic languages as a nominalizing suffix particularly productive with verbal bases. To the best of my knowledge, the analysis of its instantiation in Serbo-Croatian (SC) in Arsenijević (2010) and Simonović and Arsenijević (2014) has been the only attempt so far to capture its general morphophonological and semantic properties. This paper has two goals. The first is to present this analysis and some facts which pose problems for it, as well as to modify it to capture the problematic facts while at the same time providing a more principled account for the prosodic effects of the suffix. The second is to provide an overview of the variation in behavior of the suffix -ie across South Slavic languages in light of the category of the base, and to model it based on the modified analysis.

Section 2 introduces the nominalizing suffix -ie. Section 3 presents in more detail its properties in $\mathrm{SC}$ and section 4 focuses on its prosodic effects. In section 5, the analysis developed in Arsenijević (2010) and Simonović and Arsenijević (2014) is outlined, and some problems that it faces are pointed out. A refinement of the analysis to capture these facts is proposed in section 6 . Section 7 gives an overview of the properties of the suffix across South Slavic languages, and section 8 models the variation in terms of the analysis proposed for SC. Section 9 concludes the paper.

\section{DEVERBAL NOUNS IN -IE}

In all Slavic languages, the default pattern of derivation of deverbal nouns - the counterpart of the English -ing or German -ung derivations - involves the suffix -ie, added to the uninflected form of the passive participle.

\begin{tabular}{|c|c|c|c|}
\hline $\begin{array}{l}\text { Czech } \\
\text { lámán-í } \\
\text { broken-ie } \\
\text { 'breaking' }\end{array}$ & $\begin{array}{l}\text { Polish } \\
\text { łaman-ie } \\
\text { broken-ie } \\
\text { 'breaking' }\end{array}$ & $\begin{array}{l}\text { Russian } \\
\text { (raz)rušen-ie } \\
\text { broken-ie } \\
\text { 'breaking' }\end{array}$ & $\begin{array}{l}\text { Old Church Slavonic (OCS) } \\
\text { pleten-ie } \\
\text { knotted-ie } \\
\text { 'knitting' }\end{array}$ \\
\hline
\end{tabular}

The suffix takes different phonological and phonetic shapes across the Slavic languages, occurring as: $-j e,-i e,-e,-i$. For the sake of uniformity, I refer to it in the text and glosses as the suffix -ie.

boban.arsenijevic@uni-graz.at 
Slavic verbs are marked for grammatical aspect (e.g. Comrie 1976). Each verb bears the aspectual value imperfective or perfective. Several tests can be implemented to verify the aspectual value of the verb. For instance, in the morphological present form, only imperfective verbs may receive the progressive interpretation. Perfective verbs in this form force non-veridical meanings. ${ }^{1}$

$\begin{array}{lllll}\text { Trenutno } & \text { čitam } / * \text { pročitam } & \text { jednu } & \text { knjigu. } & \text { Serbo-Croatian }(S C)^{2} \\ \text { currently } & \text { read.1 } \mathrm{sG}^{\mathrm{Ip} / \text { rrf }} & \text { one } & \text { book } & \end{array}$

Traditional classifications also recognise a third class, termed biaspectual verbs: verbs which are both perfective and imperfective (e.g. Gladney 1982). However, since traditional imperfective verbs normally can be coerced into at least some of the perfective uses, and it is impossible to draw a clear line between biaspectuals, more easily coercable imperfectives and imperfectives which are harder to coerce - the reality of the third class is questionable. Arsenijević (2018) argues that in fact there are only biaspectual and perfective verbs, i.e. that all traditional imperfective verbs are biaspectual, but their perfective interpretations are blocked to a greater or lesser extent by antipresupposition as defined in Percus (2006), due to the availability of their marked perfective counterparts. As they are ambiguous between the two values of aspect, eventual biaspectual verbs do not participate in any contrast relevant for the topic of this paper, and therefore are irrelevant for this discussion. In the interest of simplicity, I am retaining the traditional classification, and considering only the traditional perfective and imperfective verbs.

Across Slavic languages, the deverbal noun (henceforth abbreviated as DN) suffix -ie displays different interactions with grammatical aspect, with a trivial selection of perfective bases in Old Church Slavonic (OCS), a preference for perfective basis in Russian, an equal availability of perfective and imperfective bases in Polish and Czech, a slight preference for imperfectives in Slovenian, full productivity with imperfective bases but limited productivity with perfective ones in SC, and exclusive selection of imperfective ones in Bulgarian and Macedonian. The suffix -ie also varies in the set of categories with which it combines. While in all Slavic languages it combines with verbs, and is used to derive mass and collective nouns, in some of them it also combines with verb phrases (VP), nouns (N), noun phrases (NP), adjectives (Adj), adjective phrases (AdjP) and preposition phrases (PPs), that is with different subsets of these categories.

1 There is, however, variation among Slavic languages in where the boundaries lie between the uses reserved for the perfective verbs, for the imperfective verbs, or available to both. In this section, we abstract away these asymmetries, but later they will be playing an important role in the analysis.

2 Henceforth, most examples will be from SC. Therefore, examples from SC will not be specified for language, while all other examples will. 


\section{SUFFIX -IE IN SC}

In SC, DNs in -ie from imperfective verbs are productive, compositionally interpreted and denote a homogeneous eventuality - a state or process (Simonović/Arsenijević 2014). When the base verb denotes a state or a process, this is also the eventuality denoted by the DN, as in (3a). A DN from an accomplishment denotes its process subevent or an unbounded sequence of iterations of the accomplishment, as in (3b), and a DN from an achievement denotes its preparatory stage or again an unbounded sequence of iterations of the event, as in (3c).
(3) a. spavan-je
b. jeden-je
c. dosezan-je
sleep ${ }^{\text {Ipf }}$.PASS.PTCP-ie
eat ${ }^{\mathrm{Ipf}}$.PASS.PTCP-ie
reach $^{\text {Ipf.PASS.PTCP-ie }}$
'sleeping'
'eating'
'reaching'

Examples in (4) illustrate each of the listed interpretations for the three (types of) verbs.

(4) a. a state or process:

$\mathrm{Za}$ vreme spavanja izgubite prosečno $311 \mathrm{~g}$ težine.

for time sleeping lose.2HoN on_average $311 \mathrm{~g}$ weight

'During sleep, you lose an average of $311 \mathrm{~g}$ of weight.'

b. the process component of an accomplishment:

Čišćenje dok je dete $\mathrm{u}$ kući je kao pranje zuba za vreme cleaning while is child in home is like washing teeth for time jedenja pakovanja čokolade.

eating pack.GEN chocolate.gEN

'Cleaning while a child is in the house is like brushing teeth while eating a bar of chocolate.'

c. iterations of an accomplishment:

Frakcijsko hranjenje - jedenje svaki put u malim obrocima.

fractional feeding eating every time in small meals

'Fraction feeding - eating always in small meals.'

d. the preparatory stage of an achievement:

Đivatma zadržava grubo i suptilno telo tokom dosezanja najvišeg jivatma preserves rough and subtle body during reaching highest stanja kreacije, Kailaša, čistog uma. state creation.GEN Kailash.GEN pure.gen mind.GEN 'Jivatma preserves a rough and subtle body during the reaching of the highest state of creation, Kailash, the pure mind.' 
e. iterations of an achievement:

To mu daje osećaj višestrukog dosezanja izgubljenih granica that him gives feeling multiple reaching lost.GEN borders. GEN prostora.

space.GEN

'That gives him the feeling of a multiple reaching of the lost boundaries of space.'

Only an idiosyncratic subset of perfective verbs derive DNs in SC. These DNs take three types of meanings in an unpredictable fashion: the phase transition that introduces quantization into the verb's semantics (the transition from the culmination not being reached to its being reached), as in (5a), a concrete or abstract object resulting from the eventuality described by the verb, as in (5b) and (5c), respectively.
(5) a. zaređen-je
b. zadebljan-je
c. osiguran-je
consecrate $^{\text {Prf }}$.PASS.PTCP-ie
thicken ${ }^{\text {Prf }}$.PASS.PTCP-ie
'consecration'
'bump'
secure ${ }^{\text {Prf }}$.PASS.PTCP-ie
'insurance'

According to Simonović and Arsenijević (2014), the following aspectual asymmetries can be observed on DNs in -ie in SC: DNs from imperfectives verbs are productive, compositionally interpreted and prosodically faithful to the base, while among perfective verbs they target an idiosyncratic subset of bases, show a tendency for idiomatic interpretations and bear a long-rising accent on the penultimate syllable, as illustrated in (6).

$$
\begin{aligned}
& \text { imperfective: koncèntrisan }+\mathrm{je}>\text { koncèntrisanje } \\
& \text { concentrated }+i e \quad \text { 'concentrating' } \\
& \text { perfective: izjèdnaačen }+ \text { je }>\text { izjednačénje } \\
& \text { equalized+ie 'equalization, phase-transition from } \\
& \text { a lead to a tie' (sport) }
\end{aligned}
$$

The contrasts observed are summarized in (7).

$\begin{array}{lll}\text { Productivity } & \begin{array}{l}\text { Imperfective base } \\ \text { productive }\end{array} & \begin{array}{l}\text { Perfective base } \\ \text { idiosyncratic }\end{array} \\ \text { Compositionality } & \begin{array}{l}\text { compositional } \\ \text { faithful to base }\end{array} & \begin{array}{l}\text { idiomatic } \\ \text { long rising penultimate }\end{array}\end{array}$

As already pointed out, suffix -ie does not only select verbs. With variable productivity, it also combines with nouns and NPs, adjectives and AdjPs, PPs and VPs, as illustrated in (8). In SC, the only category with which the suffix is productive apart from verbs are nouns, with some limited productivity being attested with PPs. A number of -ie-nouns from unproductive categories are inherited from older phases in the development of the language - OCS or Old Church Serbian. 
(8)

$\mathrm{N}$ (productive)
kamen-je
stone-je
'stones' (collective)
VP (not productive)
istin-o-ljub-je
truth-o-love-je
'love for truth'

NP (not productive)

mal-o-duš-je

little-o-soul-je

'despondency'

Adj (not productive)

pošten-je

decent-je

'decency'

\author{
PP (limited productivity) \\ pri-obal-je \\ by-coast-je \\ 'coastal area'
}

AdjP (not productive)
celo-mudr-ije (archaic)
whole-wise-ije
'abstinence/virginity'

The derived category is, however, fixed irrespective of the base: suffix -ie universally derives nouns and no other category. ${ }^{3}$ Moreover, the nouns it derives - unless lexicalized with an idiosyncratic meaning - tend to denote mereologically homogeneous predicates when it comes to properties of quantity; all the nouns in (8) denote homogeneous predicates. An exception are perfective DNs denoting the respective phase transition to the (holding of the) culmination state, or an object resulting from the event, which can have a quantized interpretation, as illustrated in (9).

$$
\begin{aligned}
& \mathrm{Na} \text { dnevnom redu su tri razrešen-j-a. } \\
& \text { on daily } \\
& \text { 'Three discharges are on the meeting agenda.' }
\end{aligned}
$$

\section{PROSODIC EFFECTS OF THE SUFFIX -IE IN SERBO-CROATIAN}

While all Slavic languages do indeed have the nominalizing suffix -ie, as stated in the previous section, even just within the Slavic languages, significant variation along two dimensions may be observed. One dimension is its cross-categorial productivity: does it derive nouns from bases of diverse categories, from a subset of them, or only from verbs? The other is its productivity within the verbal category: is it productive only with imperfective verbs, or with perfectives as well?

When it comes to categories, in OCS the suffix is productive across the board: in addition to verbs, it takes nouns and different kinds of NPs, adjectives and AdjPs, PPs, VPs. In Slovenian and SC, besides verbs it only productively selects for nouns, shows restricted productivity with PPs, and, not counting the nominalizations inherited from

3 Considering that the suffix -ie derives neuter gender nouns with a stem ending in a palatal segment, and that these nouns have the NSg ending $-e$, strictly speaking only $-i / j$ is the actual derivational suffix - selecting in the particular case the declension class corresponding to the neuter gender. The same suffix then occurs with the traditional masculine declension class, but only when it selects perfective verbs. It is of limited productivity in this domain and derives nouns denoting episodic quantized occurrences of events (* $(u-)$ dis $^{\text {Prf }}-a-j$ 'breath', *(za- $)$ grli $^{\text {Prf }}$-a-j 'hug', where without the perfectivizing suffix, the imperfective verb does not combine with the masculine-selecting -i/j). This also makes sense considering Arsenijević (2017), who argues that the neuter gender stands for the absence of a syntactic realization of the unit of counting, and masculine for its weak specification. In the interest of simplicity - I ignore this and other potential realizations of the suffix in the present paper. 
OCS, does not combine with any other bases. In Macedonian and Bulgarian, again leaving aside loan nominalizations from OCS, it does not take any bases other than verbs. We focus here on the facts relevant for the prosody.

While it is hard to reliably reconstruct the prosodic patterns in OCS, -ie-nominalizations inherited from it in South Slavic languages display templatic prosody, typically with properties of default assignment. This is not to say that they all have the same prosodic template, as the default prosodic assignment is sensitive to the category of the base and the phonotactic properties of the components (see Simonović/ Arsenijević 2014 for a case study of a default sensitive to the morphological and phonotactic structure).

The inherited DNs, effectively borrowed from OCS, display prosodic prominence on the stem-final syllable - not only in SC, but also in Bulgarian, and trivially so in Macedonian which has a fixed antipenultimate stress (the OCS realization of the suffix is disyllabic). In Bulgarian and Macedonian, the same pattern appears in all other -ie nominalizations too, as well as in the phonologically non-adopted ones in SC (each of the Bulgarian examples in (10), with the same prosody, occurs also in SC as a phonologically non-adopted borrowing from OCS).

$\begin{array}{llll}S C & \text { Bulgarian } & & \\ \mathrm{V} & \mathrm{V} & \mathrm{NP} & \text { Adj } \\ \text { otpuštén-je } & \text { prosvetlén-ie } & \text { blagoród-ie } & \text { pet-o-kníž-ie } \\ \text { indulged-ie } & \text { enlightened-ie } & \text { noble-ie } & \text { five-o-book-ie } \\ \text { 'indulgence (of sins)' 'enlightment' } & \text { 'nobility' } & \text { 'five-volume set' }\end{array}$

In SC, a language with a free lexically specified tone (which then determines the placement of stress), other phonologically adopted -ie-nominalizations inherited from OCS show diverse prosodic patterns, all of which display properties of default assignment. When the base is an NP, PP or VP, the suffix -ie imposes a short falling accent on the initial syllable, argued to be the main default pattern which is assigned to lexical items lacking lexical prosodic specification (Zec 1999; Simonović/Arsenijević 2014; Simonović 2020). This is illustrated in (11).

$\begin{array}{lll}\text { (11) a. NP: pëtoknjiižje } & \text { b. PP: prïobaalje } & \text { c. VP: ìstinoljuublje } \\ \text { pet-o-knjig-je } & \text { pri-obal-je } & \text { istin-o-ljub-je } \\ \text { five-o-book-ie } & \text { by-coast-ie } & \text { truth-o-love-ie } \\ \text { '5-volume set' } & \text { 'coastal area' } & \text { 'love for truth' }\end{array}$

Cases where the base consists of a morpheme lacking any prosody (because it is smaller than a syllable as in (12a), or a clitic as in (12b)) followed by a monosyllabic morpheme are an exception. There, -ie nominalizations surface with a rising accent on the initial syllable, as illustrated in (12). 

(12) a. NP: dvòknjiižje
dv-o-knjig-je
b. PP: prímoorje
two-o-book-ie
pri-mor-je
'2-volume set'
by-sea-ie
'coastal area'

Under all available models of SC lexical prosody, these nominalizations are assigned height on the second morpheme of the base - the monosyllabic one. On the assumption that the monosyllabic nature of the second morpheme somehow leave composed clitics outside of the prosodic assignment domain, prosodic assignment in these nominalizations is the same as in those in (11): high tone is assigned to the leftmost syllable in the domain. The only difference is that due to the epenthesis of a vowel or the syllabic status of the clitic morpheme, respectively, the tone may spread one syllable to the left (which is a general rule for SC, see Zec 1999) and thus surface as a raising accent. This is formally represented in (13), where the assignment of the high tone occurs before the emergence of eventual epenthetic vowels, and the latter in some cases does, while in others does not affect the surface prosody.
(13) a. (pet ${ }^{\mathrm{H}}-\mathrm{knjig}-\mathrm{je}$
b. $\left(\mathrm{pri}^{\mathrm{H}}\right.$-obal-je
five-book-ie
by-coast-ie
'5-volume set'
'coastal area'
c. (is ${ }^{\mathrm{H}}$ tin-ljub-je truth-love-ie
'love for truth'
d. dv-(knjig ${ }^{\mathrm{H}}$-je $\rightarrow$ dv-o ${ }^{\mathrm{H}}-\mathrm{knjig}^{\mathrm{H}}-\mathrm{je}$ two-book-ie
'2-volume set'
e. $p r i-\left(\mathrm{mor}^{\mathrm{H}}-\mathrm{je} \rightarrow\right.$ pri $^{\mathrm{H}}-\mathrm{mor}^{\mathrm{H}}-\mathrm{je}$ by-sea-ie
'coastal area'

When the base is a simple count noun, the derivation results in a rising antipenultimate syllable (i.e. the penultimate syllable of the stem), unless the base is monosyllabic, in which case the resulting derivation has a falling accent on the single syllable of the base (the penultimate syllable of the nominalization). This indicates that with a noun as the base, the suffix generally imposes a High tone on the stem-final syllable of the base-noun, which then spreads to the left-adjacent syllable when there is one (Zec 1999).

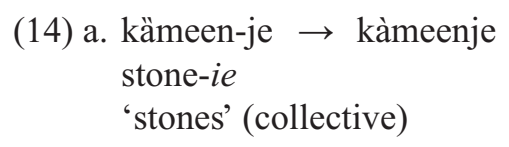
b. grân-je $\rightarrow$ grânje branch-ie 'branch' (collective)

Finally, in DNs, i.e. with verbal bases, when the verb is perfective, the prosody of the base plays no role, and the nominalization receives a pattern with a long-rising stem-final syllable, argued to be one of the default prosodic assignment patterns in SC (Simonović/Arsenijević 2014). 

(15) a. pòšten-je > pošténje decent-ie
b. ìspunjen-je $>$ ispunjénje 'decency' fulfill ${ }^{\text {Prf.PASS.PTCP-ie }}$ 'fulfillment'

Only when the verb is imperfective does the suffix preserve the prosody of the base, as in (16).
(16) a. sèčen-je > sèčenje cut $^{\text {tpf.PASS.PTCP-je }}$
'cutting'
b. dozívati > dozívanje call ${ }^{\text {IpP. }}$.PASS.PTCP-je 'calling'

All in all, -ie-nominalizations inherited from OCS which are phonologically adopted, as well as SC DNs from perfective bases, tend to display templatic prosody, in some cases clearly and in others likely emerging from default prosodic assignment. The only class in which lexically specified prosody, in particular the prosody of the base, surfaces on the $\mathrm{DN}$ are the imperfective verbs. A tentative generalization emerges that in those cases where the suffix combines with a categorized, compositionally interpreted structure - i.e. with imperfective verbs, the base-prosody is preserved. In all other cases, the surface prosody is default-looking and the suffix combines with a base which is not categorized and/or receives a non-compositional interpretation - because it is borrowed, as in the case of OCS nominalizations, or because it is a root or a rootcomplex, which is plausibly the case with perfective verbs, nouns (not the entire noun, but typically its root actually derives the -je noun, see (14)) and apparent PPs as bases. In support of PP-like bases being root-complexes, the generalization holds that only PPs with morphologically simplex prepositions and complements can be selected by the suffix, and that even though the preposition normally assigns case, the case ending fails to show up in any way in the nominalization, as illustrated in (17). This is to be expected if the base is maximally a pair of roots: that of the preposition and that of the nominal complement.

$\begin{array}{ll}\text { (17) a. za } \quad \text { brd-om } & \begin{array}{l}\text { za-brd-je } \\ \text { 'arehind hill-INST.N.SG } \\ \text { 'behind the hill' }\end{array} \\ \begin{array}{l}\text { među } \quad \text { rek-ama } \\ \text { between river-INST.F.PL } \\ \text { 'between the rivers' }\end{array} & \begin{array}{l}\text { među-rek-je } \\ \text { 'area between rivers' }\end{array} \\ \begin{array}{l}\text { b. za } \quad \text { pešč-ar-ama } \\ \text { behind sand-N-INST.N.PL ('sandpit') } \\ \text { 'behind the sandpits' }\end{array} & \begin{array}{l}\text { *za-pešč-ar-je } \\ \text { int. 'area by sandpits' }\end{array}\end{array}$


pri

kotl-in-ama

*pri-kotl-in-je

by

cauldron-N-DAT.F.PL ('ravine')

int. 'area by a ravine'

'by the ravine'

c. iz-pod brd-a

from-below hill-GEN.N.SG

'below the hill'

po-kraj rek-e

over-area river-GEN.F.SG

'next to the river'

*iz-pod-brd-je

int. 'area below the hill'

*po-kraj-rek-je

int. 'area next to/around a river'

\section{PREVIOUS ANALYSES}

\subsection{Structural Flattening Triggers Prosodic Deletion}

The only formal analysis of the prosodic, morphological and semantic properties of the suffix -ie in SC proposed so far is that in Arsenijević (2010) and Simonović and Arsenijević (2014). They observe that the opposition between the prosody faithful to the base and the pattern with a long rising penultimate syllable among derived nouns correlates with the opposition between compositional and idiomatic derivation with a range of SC derivational suffixes (besides -ie, also -ost, -stvo and others). Hence, they argue that the long-rising stem-final prosody is the outcome of the default prosodic assignment when the penultimate syllable of the base is long.

They further observe that the suffix -ie tends to derive mereologically homogeneous predicates (i.e. mass and collective nouns). Imperfective verbs also denote homogeneous predicates, while predicates denoted by perfective verbs are quantized. The central component of their analysis is that when combined with perfective bases, the homogeneous semantics of the suffix clashes with the quantization of the predicate base, leading to ungrammaticality. No such issue emerges with imperfective verbs. The only way for a passive participle of a perfective verb to combine with the suffix is if its verbal structure which specifies its perfective aspect is erased, effectively forming an adjective, i.e. - an aspectually unspecified base. Afterall, adjectivization of participles is a productive operation in SC, as well as cross-linguistically. According to this analysis, the structural flattening that lexicalizes the perfective verb into an adjective also erases its lexical prosodic specification, and the derived noun is assigned default prosody.

\subsection{Marvin (2003): Phasal Spell-Out}

An alternative analysis for the prosodic prominence of the suffix in perfective DNs which is applicable to the suffix -ie has been proposed by Marvin (2003). In her account, the suffix becomes prosodically prominent when it is a head and is spelled out together with the verbal stem, because they sit in the same phase (Chomsky 2001). 
In such a configuration, due to its syntactically stronger status as the phase head, its prosodic specification wins out, and the prosodic specification of the base fails to be realized, as it would yield two prosodically prominent syllables within the phonological word. The suffix cannot bear prominence when it is in a different phase from the base, because the base gets spelled out first, together with its prosodic specification, and by the time the suffix gets spelled out - the prosodic properties of the derived word have already been fixed to realize the specification of the base (the verb in this case).

A possible implementation of this analysis is that when the suffix -ie selects an imperfective verb, it selects an AspP which is or contains a phase (even more than one). This means that the verbal base is spelled out separately from the suffix. This explains why the prosody of such DNs is faithful to the base.

When the suffix selects a perfective verb and structural flattening applies, one could in principle argue that it results in the verbal base and the suffix being in the same phase, and hence the suffix surfaces with prosodic prominence.

This latter account faces a severe problem. Without the structural flattening from the other analysis, it requires that with imperfective bases the suffix is not in the same phase as the base, but that it is with perfective roots. Since simplex verbs are typically imperfective (there are not more than a dozen exceptions) and perfectives are typically derived from imperfective verbs, this is an unlikely structure.

Assuming structural flattening, the structure targeted by it does not include the phase head - the adjectival (or participial) suffix -en/an/t. Hence structural flattening does not get the suffix -ie to the same phase as the verbal base. The analysis hence incorrectly predicts the prosodic prominence of the verbal base. A way out could be to argue that the adjectival/participial suffix, unlike verbal and nominal category heads, does not head a phase, but it is hard to find principled support for such an argument.

\subsection{Support for Structural Flattening}

There is thus an advantage in the analysis relying on structural flattening and prosodic deletion. The view that perfective DNs rely on an operation that turns a structurally complex verb into a root, resulting in the lexical storing of its meaning instead of a compositional interpretation, is supported by the observation that -ie nominalizations from perfective verbs are indeed extremely prone to having idiomatic interpretations significantly narrower than those of their base verbs, or metaphorically shifted ones. Their interpretations moreover vary unpredictably between an object and a phase transition to the culmination state, whether abstract or resulting from the described eventuality, as illustrated in (5) above and in (18).

(18) Imperfective, compositional hlad-jen-je cold $^{\text {Ipf }}$-PASS.PTCP-ie 'cooling'
Perfective, lexicalized (idiosyncratic)

za-hlad-jen-je

for-cold ${ }^{\text {Prf-PASS.PTCP-ie }}$

'a weather-change to colder' 

Perfective, OCS-loan (idiomatic)
prikazanje
OCS-loan ${ }^{\text {Prf }}-i e$
'vision'
Perfective (compositional): impossible
(*za)-lom-jen-je (za-lom-jen 'chipped')
for-break ${ }^{\text {Prf }}$-PASS.PTCP-ie
'breaking' (not 'chipping')

Additional support for the correspondence between idiomatized meanings and the prosodic pattern comes from the imperfective DNs. Though rare, cases exist where an imperfective verb derives a DN with a shifted interpretation. All such DNs surface with the prosodic template of perfective nominalizations: a long rising accent on the penultimate syllable. The idiomatic, idiosyncratic DN then exists parallel to the productive, compositional one. This is illustrated in (19).

\section{Base verb}

\begin{tabular}{|c|c|c|c|c|}
\hline $\begin{array}{l}\text { putòvati' }{ }^{\mathrm{Ipf}} \\
\text { 'to travel' }\end{array}$ & $>$ & $\begin{array}{l}\text { putòvaanje } \\
\text { 'travelling' }\end{array}$ & / & $\begin{array}{l}\text { putovánje } \\
\text { 'trip' }\end{array}$ \\
\hline $\begin{array}{l}\text { òbrazovati }{ }^{\mathrm{Ipf}} \\
\text { 'to form/educate' }\end{array}$ & $>$ & $\begin{array}{l}\text { òbrazovaanje } \\
\text { 'forming/educating' }\end{array}$ & 1 & $\begin{array}{l}\text { obrazovánje } \\
\text { 'education' }\end{array}$ \\
\hline $\begin{array}{l}\text { òdlikovatitpf } \\
\text { 'to decorate' }\end{array}$ & $>$ & $\begin{array}{l}\text { òdlikovaanje } \\
\text { 'decorating' }\end{array}$ & & $\begin{array}{l}\text { odlikovánje } \\
\text { 'medal' }\end{array}$ \\
\hline
\end{tabular}

\subsection{Weaknesses of the Analysis}

A weak point of the analysis proposed by Arsenijević (2010) and Simonović and Arsenijević (2014) is its (lack of an explicit) account for the deletion of the prosody of the base. It links it to the conversion of the structurally complex verbal participle into a simple adjective by the flattening of its internal structure, but is not specific about the particular operation responsible for the deletion and how it is triggered by the structural flattening.

Moreover, it has been argued (e.g. Trezner 1970) that the set of perfective verbs deriving -ie nouns is not entirely idiosyncratic. On a closer look, it turns out that it is almost exclusively the morphologically complex perfective verbs which are not compositionally interpreted from the meaning of an imperfective base verb and a prefix that combine with the suffix (which we shall term primary perfective verbs). There are two big classes of such verbs: idiomatic perfectives, as in (20a), where the verb involves an intransparent root which is idiosyncratic for this verb (observe the absence of a corresponding passive participle even without the prefix), and those borrowed from OCS, as in (20b). ${ }^{4}$

4 OCS verbs have a hybrid status regarding complexity. They involve prefixes which are always homophonous with SC counterparts (even when OCS had a different realization for a prefix, it is adapted to its SC counterpart) and simple verbs which may or may not have SC counterparts, and for this reason they are identified as morphologically complex. However, their meaning is typically not compositional in this regard, so they are recognized as very similar to idiomatic verbs. 

(20) a. pri-sp-et-je
*sp-et
by-?? ?rf-PASS.PTCP-ie ??-PASS.PTCP
b. prestavi-en-je
pass_over ${ }^{\mathrm{Prf}}{ }_{\mathrm{OCS}}$-PASS.PTCP-ie
'arrival'
'death' (the event)

This puts the structural flattening in a different perspective. If the perfective verbs deriving DNs are already non-compositional, then the structural flattening is not a last resort operation licensing the derivation of a $\mathrm{DN}$, but rather occurs as an independent property of the verb that makes its participle available to the DN derivational pattern.

There seem nevertheless to be additional factors involved, as not all primary perfectives (those derived from morphologically simple imperfectives) derive DNs. Some of them do not sound perfect, such as the example in (21a), but become much more acceptable in an appropriate context, as in (22a). Others, like the one in (21b), remain bad across salient contexts - see (22b).

(21)

\begin{tabular}{|c|c|}
\hline $\begin{array}{l}\text { ruš-en } \\
\text { destroy } \\
\text { 'destroyed'PASS.PTCP }\end{array}$ & $\begin{array}{l}\text { ruš-en-je } \\
\text { destroy } \\
\text { 'destroying'PASS.PTCP-ie }\end{array}$ \\
\hline $\begin{array}{l}\text { pre-ruš-en } \\
\text { over-dress } \\
\text { 'disfrisuised'PASS.PTCP }\end{array}$ & $\begin{array}{l}\text { ?pre-ruš-en-je } \\
\text { over-dress }{ }^{\text {Prff-PASS.PTCP-ie }} \\
\text { 'getting disguised' }\end{array}$ \\
\hline $\begin{array}{l}\text { građ-en } \\
\text { builddpf-PASS.PTCP-ie } \\
\text { 'built' }\end{array}$ & $\begin{array}{l}\text { građ-en-je } \\
\text { builddpf-PASS.PTCP-ie } \\
\text { 'building' }\end{array}$ \\
\hline $\begin{array}{l}\text { na-građ-en } \\
\text { on-build } \\
\text { 'awrf-PASS.PTCP } \\
\text { 'arded' }\end{array}$ & $\begin{array}{l}\text { ??na-građ-en-je } \\
\text { on-build } \\
\text { 'getting -PASS.PTCP-ie } \\
\text { 'garded' }\end{array}$ \\
\hline
\end{tabular}

(22) a. Njegovim prerušenjem u boga kiše his.INST disguising.INST in god rain.GEN počinje prolećni ritual plodnosti. begins spring ritual fertility.GEN 'With him disguising into the god of rain begins the spring ritual of fertility.'

b. ?"Njegovim nagrađenjem za životno delo počinje his.INST awarding.INST for life achievement.GEN begins festival vina. festival wine.GEN 'With him receiving the life achievement award begins the festival of wine.' 
Note that both sentences in (22) would be fine with the respective imperfective DNs, but with a different interpretation. In that case, it would be the process or the preparatory stage, and not the phase transition into the culmination state that marks the beginning of the ritual, i.e. of the festival, respectively.

The problem that emerges with this change of perspective is that it implies that the idiomatic semantics does not emerge through the structural flattening of the participle required for nominalization as previously argued, but rather presents an independent property of the verb. The participle then cannot be aspectually different from the verb, i.e. it is perfective and quantized.

Moreover, primary perfectives quite regularly derive secondary imperfectives with which they establish aspectual pairs: the two verbs semantically minimally differ in the aspectual value, as in (23). The view in Arsenijević (2010) that -ie, which derives mereologically homogeneous predicates, takes imperfective bases because they also denote homogeneous predicates, predicts that here, too, -ie will combine with the secondary imperfective only, which will block the DN derived from the perfective verb. However, such perfective verbs still derive DNs on their idiomatic interpretation, while the DNs from their imperfective counterparts preserve the compositional interpretation.

$$
\begin{array}{llll}
\text { po-stavi-ti : } & \text { po-stavi-a-ti } & \text { u-blaži-ti : } & \text { u-blaži-va-ti } \\
\text { over-put } & \text { Prf-INF } & \text { over-put-IPF Ipf-INF } & \text { in-milden } \\
\text { 'place' (Prf) } & \text { 'place' (Ipf) } & \text { 'milden' (Prf) } & \text { 'm-milden-(PPF } \\
\text { postavljenje } & \text { postavljanje } & \text { ublaženje } & \text { ublaživanje } \\
\text { 'appointment' } & \text { 'placing' } & \text { 'mildening' } & \text { 'mildening' } \\
& \text { 'appointment' } & \text { (of measures) } & \text { (any) }
\end{array}
$$

If idiomatization is not a tool to enable perfective DNs but an independent process, then why are perfective -ie DNs available in the first place? Why is the -ie DN of verbs like in (23) not derived only from the secondary imperfective? In particular since there are also DN suffixes restricted to perfective verbs, such as $-a j$ and $-a$ illustrated in (24): why does a perfective verb combine with the homogeneous, rather than a quantized DN suffix?

$$
\begin{aligned}
& \text { u-dis-aj po_kuš-aj iz_daj-a pro_val-a } \\
& \text { in-breathe }{ }^{\mathrm{Prf}}-a j \text { try }{ }^{\overline{\mathrm{Pr}}-}-a j \quad \text { betray }{ }^{\mathrm{Prf}}-a \text { break }{ }_{-} \text {in }^{\mathrm{Prf}}-a \\
& \text { 'inbreath' 'try }{ }_{\mathrm{N}}{ }^{2} \text { 'betrayal' 'burglary' }
\end{aligned}
$$

\section{A MODIFIED ANALYSIS}

In this section, I present a modification of the analysis presented in section 5, necessary to capture the empirical insights from subsection 5.4, as well as an extension based on Simonović (2019), which gives a principled and independently motivated account for the prosodic regularities. 


\subsection{Suffix -ie in SC May Select Roots - It Is Only Incompatible with a Quantized AspP}

A small modification of the analysis from Arsenijević (2010) and Simonović and Arsenijević (2014) suffices to account for the observed facts. Idiomatic and borrowed primary perfective verbs are regular perfectives, yet their perfectivity is not structurally derived but stored as part of the lexical semantics of their respective roots. They are thus effectively non-derived perfectives. Their intransparent semantics triggers their storing in the lexicon as roots. For instance, the intransparent meaning of the morphological complex $u$-stolic 'in-chair' (meaning enthrone rather than into (a) chair) triggers the storing of the complex in the lexicon as a root instead of a compositional interpretation in a verbal structural sequence, as illustrated in (25).

[AspP u- $\left[\mathrm{vP}[\mathrm{x}]-\mathrm{i}\left[[\mathrm{y}] \sqrt{\text { STOLIČ }}_{[[\mathrm{y}] \mathrm{u}[\mathrm{z}]]]]}^{\rightarrow} \rightarrow\right.\right.$ Vustolič $\lambda x \lambda y \lambda e[\exists e 1, e 2$. cause $(e, e 1, e 2) \& \operatorname{act}(e 1, x) \& \operatorname{in}(e 2, y, z) \& \operatorname{chair}(z)$

When these verbs take verbal inflection, they project the perfective structure with the respective aspectual head filled by a null element (with possible head-movement into it by the root and the material it picks up). However, when they build DNs, the roots are directly selected by the adjectival suffix -en/an/t. This structure is then selected by the DN suffix -ie. This is illustrated for the two verbs from (20), one idiomatized and one borrowed primary perfective, in (26) below.

(26)
a. $\left[\mathrm{TP}-\mathrm{m}\left[\mathrm{AspP}-\varnothing\left[\mathrm{vP}-\mathrm{i}\left[\sqrt{U S T O L I C ̌}_{\text {U }}\right]\right]\right]\right.$ ustolič-i-m
enthrone- $\theta$ vowel-1SG
'I enthrone'
b. $[\mathrm{TP}-\mathrm{m}[\mathrm{AspP}-\varnothing[\mathrm{vP}-\mathrm{i}[\sqrt{\mathrm{OSVES}} \mathrm{T}]]]]$ osvešt-a-m sanctify- $\theta$ _vowel-1sG 'I sanctify'
$\left[\mathrm{nP}-\mathrm{ie}\left[\operatorname{adj} \mathrm{P}-\mathrm{n}\left[\mathfrak{V}_{\text {USTOLIČ }}\right]\right]\right.$
$\sqrt{\text { USTOLIČ-en-je }}$
in-throne ${ }^{\text {Prf }}$-ADJ-ie
'enthronement'
$[\mathrm{nP}-\mathrm{ie}[\operatorname{adj} \mathrm{P}-\mathrm{n}[\sqrt{ }$ OSVEŠT $]]]$
VosvešT-an-je
'sanctification'
sanctify ${ }^{\text {Prf }}{ }_{\text {OCS }}$-ADJ-ie

Rather than triggering the flattening of the perfective verbal structure to delete its quantized semantics, the suffix -ie simply selects for the suffix -en/an/t which in turn does not select a quantized AspP but a root (for a general overview of the suffix -en/ $a n / t$, see Simonović/Arsenijević 2014). Suffix -en/an/t selecting a root is a proper target on this view.

This means that, in principle, for every verb the suffix may select either the fullyfledged passive participle - as long as its AspP is not specified as quantized, or just the root combined with the adjectivizing suffix. 
With imperfective verbs, both options are available, the participle being preferred due to its compositional interpretation. Therefore, imperfective verbs productively derive compositional DNs, and idiosyncratically root-based ones, i.e. only where an idiomatic interpretation is pragmatically supported, as in (19).

With perfective verbs, the option with the participial base is not available, as it involves an AspP specified for quantization. Idiomatic primary perfective verbs act as roots available as legitimate bases for DNs.

But on this view, structural flattening cannot be responsible for the prosodic effects. If it had such effects, they should be visible already on the primary perfective verbs.

\subsection{Radical Cores}

The prosodic contrast between the prosody faithful to the compositional base and the default-looking prosody of DNs with root-bases receives a neat explanation from the model proposed by Lowenstamm (2014), in particular in the version developed for the South Slavic data in Simonović (2019). Lowenstamm argues within the framework of Distributed Morphology (DM, Halle/Marantz 1993) that (at least some) derivational morphemes are roots. He views these roots as semantically light, and dissociates them from the functional effects that they coincide with - such as the category change. Category change does not come from these suffixes, but from an independent phonologically null category head.

Simonović, also in the framework of DM, radicalizes Lowenstamm's view that some derivational affixes are roots: he takes all phonological material to come from roots and all functional material to be phonologically empty. Traditional derivational suffixes are chunks of structure consisting of an empty category head and a light root (the one surfacing as the suffix), which are stored in the Encyclopedia. Simonović provides additional empirical support for this view, and argues that in Slovenian, configurations with at least one functional head between every two roots results in resolved prosody (i.e. surface prosody matching the lexical specification of one of the components), illustrated in (27a), and configurations with radical cores (structural segments consisting of two or more structurally adjacent roots without any intervening functional items) trigger default prosody, as in (27b).

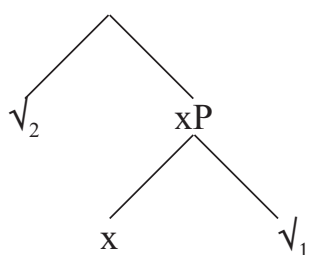

(27) a. Resolved prosody (typically, lex. prosody of $\sqrt{ }_{1}$ surfaces)

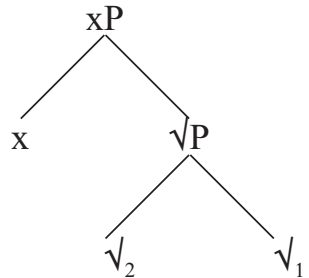

b. Default prosody 
Simonović argues, based on minimal pairs such as those with the deadjectival nominalizing suffix -ost in (28), that prosody faithful to the base surfaces in compositionally interpreted derivations because they involve no radical cores, while their idiomatically interpreted counterparts carry the default stress, which is stem-final in Slovenian.

$$
\begin{array}{llll} 
& \text { stár 'old' + ost } & \text { Slovenian } \\
\text { stárost 'oldness' } & & \text { staróst 'old age' }
\end{array}
$$
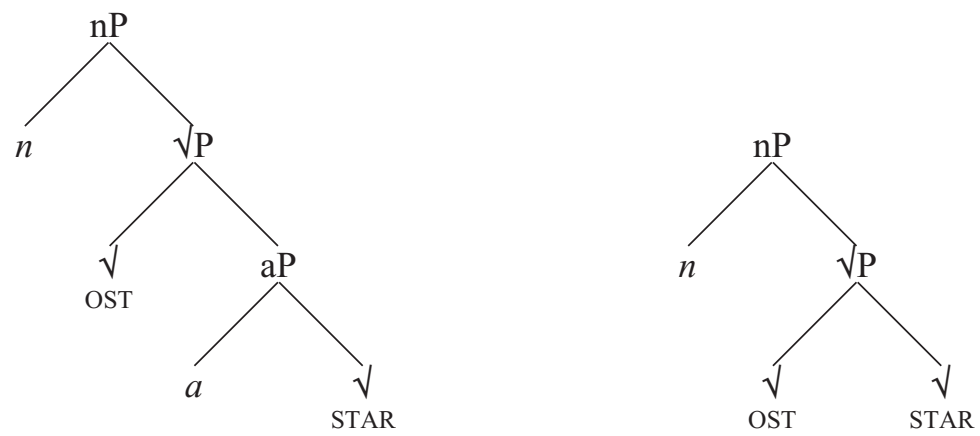

\subsection{Applying the Modified Analysis to SC DNs}

With this view adopted, the default stress does not require deletion - it is straightforwardly predicted from the root status of the base. Consider (29), where the structural contrast from Simonovic is applied to the minimal pair of two DNs derived from the same verb. One DN is derived from the participle, i.e. from the combination of the adjectivizing chunk (i.e. $\left[{ }_{\mathrm{aP}} a\left[\sqrt{\mathrm{AN}}_{\ldots} ..\right]\right]$ ) and the verb (the $\mathrm{vP}$ ), as represented in (29a). The other is formed from the combination of the adjectivizing chunk with a root complex, as represented in (29b). ${ }^{5}$

5 At the merger of two roots, one of them semantically projects, by projecting its ontological class. The emerging asymmetry can be stipulated to suffice to drive the LF interpretation, as well as the phonological linearization, but fails to properly feed the prosodic processing, thus resulting in the default prosody assignment. 
(29) a. A compositional DN, no radical cores

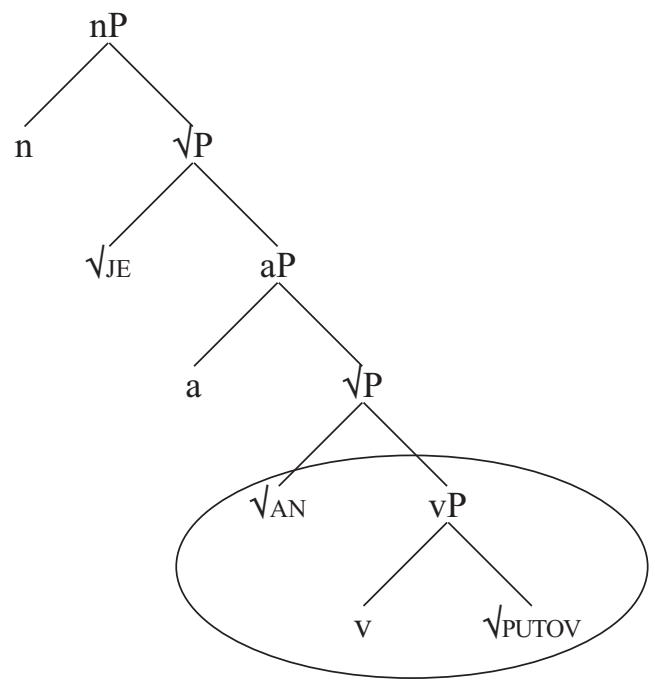

b. An idiomatic DN: a radical core

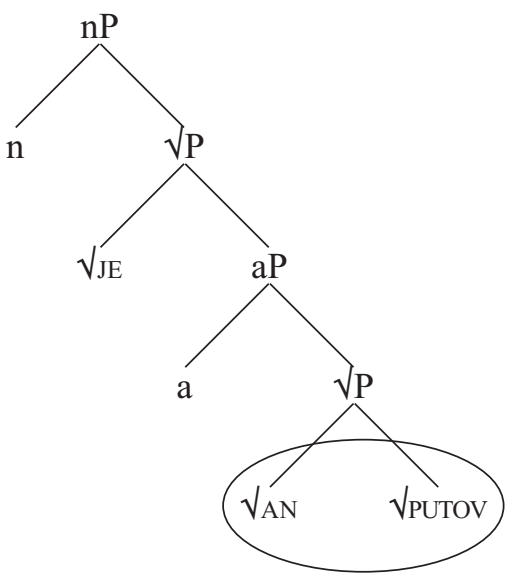

This analysis both fits the data better, considering that the perfective verbs with corresponding DNs are independently idiomatized and that imperfective verbs also may derive idiomatic DNs with the default prosody, and also provides a principled account for the assignment of default prosody.

\section{SUFFIX -IE ACROSS THE SOUTH SLAVIC LANGUAGES}

South Slavic languages show a great deal of variation in the productivity and selection properties of the suffix -ie.

\subsection{OCS}

In OCS, the suffix is highly promiscuous and productive. It productively combines with PPs, nouns and NPs (involving numerals or attributive adjectives), verbs and VPs, adjectives and AdjPs, as illustrated in (30) and (31).

(30)

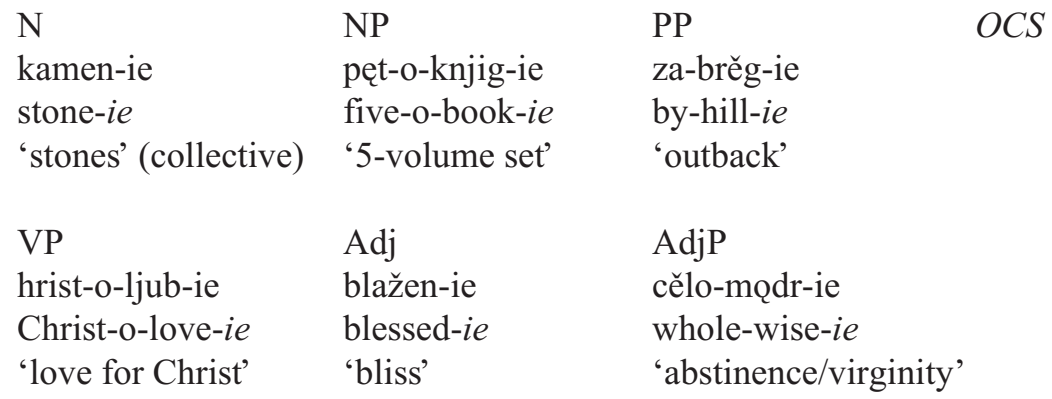


Both imperfective and perfective verbs in OCS derive DNs, but perfective DNs are about ten times more frequent. A vast majority of imperfective nominalizations, if not all, are of the idiomatized type, in the sense that they do not denote the process component of the described event, but typically its product. This is illustrated by the DNs deriving from imperfective verbs in (31), where rather than denoting, respectively, the states of knowing (znanie), of not bearing (neterpenie), the preparatory states or processes of blinking (mgnovenie) and reading (čtenie), each of them denotes an individual associated with the event-kind described by the base.

im-an-ie zn-an-ie ne-terp-en-ie mgnov-en-ie čt-en-ie $O C S$ have-PASS.PTCP-ie know-PASS.PTCP-ie not-bear-PASS.PTCP-ie blink-PASS.PTCP-ie read-PASS.PTCP-ie 'property' 'knowledge' 'impatience' 'moment' 'text'

Finally, the passive participle in -en/an/t in OCS is universally perfective, irrespective of the grammatical aspect of the verb, which means that ultimately all the bases of $-i e$ DNs in OCS are perfective. In other words, the OCS suffix -ie effectively selects no imperfective (i.e. homogeneous) bases whatsoever. This is probably also the explanation for the preference that the suffix shows for perfective verbs: these verbs are more likely to be used in the perfective passive participle form.

\subsection{Macedonian and Bulgarian}

In Macedonian and Bulgarian, the picture is the exact opposite. The suffix only combines with imperfective verbs, and in this domain it is fully productive, see the examples in (32a). Native perfective verbs do not derive DNs - see (32b). Both languages have a limited number of perfective DNs inherited from OCS or Russian Church Slavonic (RCS), but these are clearly marked as borrowed, rather than derived words. In both languages, their ending differs segmentally from the native DN suffix, and in Bulgarian they are also characterized by the antepenultimate stress inherited from the source language. The DNs borrowed from OCS and RCS, include a small number of imperfective idiomatic ones. Three such Bulgarian DNs of OCS origin, two perfective and one imperfective, are given in (32c).

\begin{tabular}{|c|c|c|}
\hline $\begin{array}{l}\text { a. bjága-n-e } \\
\text { run }^{\text {Impf-PASS.PTCP-ie }} \\
\text { 'running' }\end{array}$ & $\begin{array}{l}\text { kára-n-e } \\
\text { drive }{ }^{\text {Impf-PASS.PTCP-ie }} \\
\text { 'driving' }\end{array}$ & $\begin{array}{l}\text { mísle-n-e Bulgarian } \\
\text { think }{ }^{\text {Inpf-PASS.PTCP-ie }} \\
\text { 'thinking' }\end{array}$ \\
\hline $\begin{array}{l}\text { b. *iz-bjága-n-e } \\
\text { away-run'Prf-PASS.PTCP-ie } \\
\text { 'running' }\end{array}$ & $\begin{array}{l}\text { *pre-kára-n-e } \\
\text { over-drive }{ }^{\text {Impf }-P A S S . P T C P-i e} \\
\text { 'driving' }\end{array}$ & $\begin{array}{l}\text { *iz-mísle-n-e } \\
\text { out-think } \\
\text { 'thinking'-PASS.PTCP-ie }\end{array}$ \\
\hline
\end{tabular}




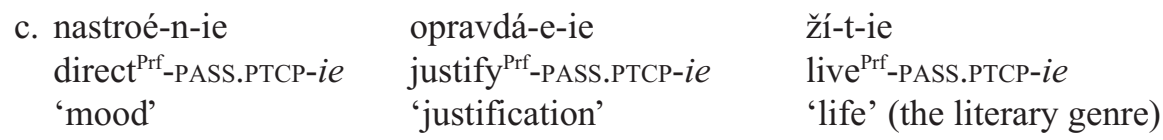

\subsection{Serbo-Croatian}

As already discussed, suffix -ie is fully productive with imperfective verbs, and limited to (a subset of) those perfectives which are not compositionally derived. It also productively combines with nouns, deriving collectives, and with limited productivity with PPs, deriving mass nouns.

\subsection{Slovenian}

When it comes to non-verbal bases, suffix -ie in Slovenian behaves like SC: it productively combines with nouns, and with limited productivity also with PPs. When it comes to verbs, a difference can be observed. Like in Bulgarian, Macedonian and SC, the suffix is productive with imperfective verbs (although for some bases blocked by other DN suffixes, in particular $-v a$ ). Unlike in these other three contemporary South Slavic languages, in Slovenian, the suffix -ie is also relatively productive with perfective verbs, and certainly not limited to the loan vocabulary and/or the idiomatic perfective verbs. This is illustrated in (33).

(33)

PP (limited productivity)

pod-kolen-je

under-knee-je

'knee pit (area)'
N (productive)

list-je

leaf-je

'leaves' (collective)
Slovenian

Perfective V (productive)

raz-cvet-an-je

away-flower ${ }^{\text {Prf-PASS.PTCP-je }}$

'blooming'

Some of the perfective DNs give a first impression of degradation, but they most often improve in an adequate context, and can easily be found in colloquial use. In any case, there is a large number of compositionally interpreted ones like razcvetanje 'blooming' above, podkurjenje 'lighting up', začaranje 'enchantment', which would be out in Macedonian, Bulgarian and SC.

Finally, Slovenian DNs differ from all others in systematically preserving the prosody of the base, irrespective of its grammatical aspect. Consider the examples in (34). Both stand for a pair of verbs, one with the prefix in brackets and the other without it (prečiščenje and čiščenje, začudenje and čudenje). Prefixed versions are perfective and prefixless imperfective. In both variants, each of the two DNs has the same prosody that inherited from the base.

$$
\begin{aligned}
& \text { (pre)-číst-iti } \\
& \text { overer }^{\text {Prf-clean }}{ }^{\text {Ipf-INF }} \\
& \text { 'clean (up)' }
\end{aligned}
$$

$$
\begin{aligned}
& \text { (za-)čúd-iti } \\
& \text { for }{ }^{\mathrm{Prf}} \text {-wonder }{ }^{\mathrm{Ipf}}-i t i \\
& \text { '(begin to) wonder' }
\end{aligned}
$$

Slovenian 


$$
\begin{aligned}
& \text { (pre)-číst-jen-je ((pre)číščenje) (za-)čúd-en-je } \\
& \text { over }^{\text {Prf }} \text {-clean }{ }^{\text {Iff }} \text {-PASS.PTCP-je } j \text { for }{ }^{\text {Prf }} \text {-wonder }{ }^{\text {Iff-PASS.PTCP-je }} \\
& \text { 'cleaning (up)' 'wondering / beginning to wonder' }
\end{aligned}
$$

Simonović (2019) points out a small number of exceptions with a stem-final stress.

$$
\begin{array}{ll}
\text { míšljen }>\text { mišljén-je, *míšljen-je } & \text { vprášan > vprašán-je, *vprášan-je } \\
\text { 'thought' 'opinion, thinking' } & \text { 'asked' 'question' }
\end{array}
$$

All these exceptional DNs involve idiomatic perfective bases.

\section{MODELLING VARIATION}

The main observations based on the overview of the suffix -ie in South Slavic are the following:

1. There is a substantial difference between the behavior of the suffix -ie in OCS and in the contemporary South Slavic languages: in OCS it is quite unselective, and combines with several types of expressions that are unavailable to it in the four living varieties: with different kinds of NPs, with adjectives and AdjPs, and with VPs. In Slovenian and SC, the suffix is productive with nouns and shows restricted productivity in the PP domain, while in Bulgarian and Macedonian it is limited to imperfective verbs.

2. It takes only perfective bases in OCS, both perfective and imperfective in SC and Slovenian - with a strong preference for imperfective bases in SC, and a mild one in Slovenian, and only imperfective bases in Bulgarian and Macedonian.

I propose the following account. The suffix -ie is the default nominalizer in OCS, while in the living South Slavic varieties it has grammaticalized to carry homogeneous semantics. In OCS, it takes (homogeneous and) quantized bases (perfective verbs, numeral-noun expressions), in contrast to the living varieties, where it avoids the latter. Among the contemporary South Slavic languages, only in Bulgarian and Macedonian, it is further restricted to the verbal category. It prefers perfective bases in OCS because they are more likely to derive the form that it selects: the perfective passive participle. In SC and Slovenian, it combines with verbal bases, and - under pragmatic licensing - also with roots.

Where both are available and semantically equivalent, the suffix prefers compositional bases to roots. The reason why it shows a decent degree of productivity with perfective bases in Slovenian is that Slovenian verbal aspect has significantly bleached the quantized semantics of the perfective verbs. This observation has been made independently (Dickey 2003), and can be supported by many contrasts, such as for instance the availability of perfective verbs in different homogeneous contexts, in which they cannot be used in other Slavic languages. Consider the contrasts in the use of perfective verbs for the present performative semantics (36). 
Obljubim, da tega ne bom več naredil. : *Obećam da to više neću raditi. promise $^{\mathrm{Prf}} .1 \mathrm{sG} . .$. promise $\mathrm{Prr}^{\mathrm{Pr}} .1 \mathrm{SG} .$.

'I promise I won't do that ever again.'

Priznamo. Strah nas je.

: *Priznamo. Strah nas je. $\operatorname{admit}^{\text {Prf }} .1$ PL... admit $^{\mathrm{Pr}} .1$ PL...

'We admit it. We're afraid.'

We arrive at a picture where suffix -ie has been grammaticalized from a general nominalizer in OCS into one restricted in terms of the category and properties of quantity of the base in all the living South Slavic languages. In Bulgarian and Macedonian it is specified to select only verbal bases, in Slovenian and SC - roots are valid targets as well, and in OCS its domain is categorially unrestricted. The weakened quantized semantics of perfectives in Slovenian licenses a more liberal combination of the suffix with verbal bases regarding the grammatical aspect.

\section{CONCLUSION}

This paper has focused on two different perspectives of -ie-DNs: an analysis of DNs in contemporary SC and the variation across South Slavic languages. After presenting the main properties of -ie nominalizations, a modified analysis is proposed to fit the observation that the perfective verbs which derive DNs are all already idiomatically interpreted. It is further combined with the Lowenstammian model of prosodic assignment from Simonović (2019) in order to capture the prosodic effects of the suffix in a principled way.

An overview of the general situation in South Slavic is provided, which is then modelled in terms of the analysis proposed for SC with a refinement varying the specification of the suffix across the target languages. The empirical contrasts observed are shown to follow from two aspects of the specification of the suffix: whether it is sensitive to the structurally realized quantization, and whether it is restricted to verbs.

Its good fit to the South Slavic data lends additional support to Lowenstamm's (2014) and Simonović's (2019) view of derivational suffixes as roots, and to the analysis by the latter where radical cores, i.e. structurally adjacent roots, result in default prosody.

\section{References}

ARSENIJEVIĆ, Boban (2010) "On two types of deadjectival nominalisation in Serbian." Suvremena lingvistika 36/70, 129-145. https://hrcak.srce.hr/62322 ARSENIJEVIĆ, Boban (2017) "Gender, like classifiers, specifies the type of partition: Evidence from Serbo-Croatian.” In: J. Kantarovich/T. Truong/O. Xherija (eds), Proceedings of the $52^{\text {nd }}$ Annual Meeting of the Chicago Linguistic Society. Chicago: Chicago Linguistic Society, 21-37. 
ARSENIJEVIĆ, Boban (2018) "Serbo-Croatian suffix -va and the illusion of the imperfective specification." Paper presented at the conference Ambigo: Workshop on Ambiguity - Theory, Development, and Processing, University of Göttingen on 4-6 July 2018. Gottingen: University of Göttingen.

COMRIE, Bernard (1976) Aspect. Cambridge: Cambridge University Press.

DICKEY, Stephen M. (2003) "Verbal Aspect in Slovene." In: J. Orešnik/D. F. Reindl (eds), Sprachtypologie und Universalienforschung 56/3. Berlin: Akademie Verlag, 182-207.

GLADNEY, Frank Y. (1982) "Biaspectual Verbs and the Syntax of Aspect in Russian." The Slavic and East European Journal 26/2, 202-215. https://doi. org/10.2307/308089

HALLE, Morris/Alec MARANTZ (1993) "Distributed morphology and the pieces of inflection." In K. Hale/S. J. Keyser (eds), The View from Building 20: Essays in Linguistics in Honor of Sylvain Bromberger. Cambridge, MA: MIT Press, 111-176.

LOWENSTAMM, Jean (2014) "Derivational affixes as roots: Phasal spell-out meets English stress shift.” In: A. Alexiadou/H. Borer/F. Schafer (eds), The syntax of roots and the roots of syntax. Oxford University Press: Oxford, 230-259.

MARVIN, Tatjana (2003) Topics in the stress and syntax of words. Doctoral dissertation. Cambridge, MA: Massachusetts Institute of Technology.

PERCUS, Orin (2006) "Antipresuppositions." In: A. Ueyama (ed), Theoretical and Empirical Studies of Reference and Anaphora: Toward the establishment of generative grammar as an empirical science, Report of the Grant-in-Aid for Scientific Research (B), Project No. 15320052. Fukuoka: Japan Society for the Promotion of Science, 52-73.

SIMONOVIĆ, Marko/Boban ARSENIJEVIĆ (2014) "Regular and honorary membership: On two kinds of deverbal nouns in Serbo-Croatian." Lingue e linguaggio 13/2, 185-210. https://doi.org/10.1418/78407

SIMONOVIĆ, Marko (2019) "Radical core, prosody preservation and default stress: Revisiting Slovenian nominalisations." Manuscript. Graz: University of Graz.

SIMONOVIĆ, Marko (2020) “Tonal spans in Neo-Štokavian.” Manuscript. Graz/Nova Gorica: University of Graz/University of Nova Gorica.

TREZNER, Tomislav (1970) "Glagolske imenice na -nje." Jezik: časopis za kulturu hrvatskoga književnog jezika 18/2, 50-54.

ZEC, Draga (1999) "Footed tones and tonal feet: rhythmic constituency in a pitch-accent language." Phonology 16, 225-264. https://doi.org/10.1017/S0952675799003759 


\section{Abstract \\ DEVERBAL NOUNS IN -IE AND THEIR VARIATION \\ ACROSS THE SOUTH SLAVIC AREA}

The paper proposes an analysis of the correlation between the semantic and prosodic properties of the suffix -ie and of its variation across the South Slavic languages. Empirical facts about the suffix are outlined, and previous analyses are presented and confronted with empirical and theoretical problems. A slight modification of the analysis of Arsenijević (2010) and Simonović and Arsenijević (2014) enables its combination with the model from Simonović $(2019,2020)$. The combined analysis neatly accounts for the facts. A model of the variation in the behaviour of the suffix across South Slavic languages is formulated in terms of the modified analysis.

Keywords: deverbal nominalizations, radical cores, South Slavic, grammatical aspect, default prosody

\section{Povzetek \\ IZGLAGOLSKI SAMOSTALNIKI Z MORFEMOM -IE IN NJIHOVE RAZLIČICE V JUŽNOSLOVANSKIH JEZIKIH}

Prispevek predstavi analizo korelacije med pomenskimi in prozodičnimi lastnostmi morfema -ie in njegovih različic $v$ južnoslovanskih jezikih. $V$ članku orišemo empirična dejstva, predstavimo dosedanje razčlembe ter navedemo z njimi povezane empirične in teoretične zagate. Razprava nato preoblikuje analizo Arsenijevića (2010) in Simonovića in Arsenijevića (2014), tako da postane združljiva z modelom Simonovića (2019, 2020). Delno preoblikovana razčlemba lepo pojasni obravnavane podatke; prispevek $\mathrm{z}$ njeno pomočjo uvede model, ki razloži razlike $\mathrm{v}$ vedenju obravnavanega morfema $\mathrm{v}$ južnoslovanskih jezikih.

Ključne besede: izglagolske nominalizacije, korenski skupek, južnoslovanski jeziki, slovnični vid, privzeta prozodija 